\title{
Spatial Barriers and the Tendency of the Utilization of Mediated Citizenship by Villagers in Accessing Public Services
}

Rahmad Hidayat ${ }^{\mathbf{1}}$

STISIP Mbojo Bima, Indonesia

rahidsmart@gmail.com

Akhyar ${ }^{2}$

STISIP Mbojo Bima, Indonesia

akhyarstisip@gmail.com

\section{Muhammad Sauki ${ }^{3}$}

STISIP Mbojo Bima, Indonesia

muhammad.sauqi2014@gmail.com

\author{
E-ISSN (2721-0642) \\ Received: \\ January 262021 \\ Revised: \\ March 182021 \\ Accepted: \\ April 22021 \\ Doi Number \\ https://doi.org/10.37950/ijd.v3i1.82
}

\section{Abstract}

This paper aims to discuss the dynamic intersection between the spatial barriers and the tendency of the utilization of "mediated citizenship" by villagers in accessing public services. It is important to map out how villagers interact with authoritative service providers at the local government level, which is not done directly, but through the mediation of a third party, namely a local NGO that is implementing a program in their village. Based on the context of Oi Bura Village, the tendency of the utilization of mediator services of "LAKPESDAM PCNU Kabupaten Bima" in accessing public services (especially the residential identities) began to take shape because it was triggered by the poor people's consideration about the spatial stretch of their village area with the site of the service provider that would have an impact on financial expenses and bureaucratic severity factors that must be passed when accessing these basic services. Although the residential identities should be obtained automatically based on formal status as an Indonesian citizen, in practice the access of the poor villagers to basic services is achieved through a third party mediation role. The limitations of the service providers' responsiveness, accountability and institutional capacity to act proactively in solving the public problems are increasingly opening up the chance for "permanence" of facilitation of the state-citizen interaction by third parties.

Keywords: access, citizenship, mediator, service, space 


\section{Abstrak}

Makalah ini bertujuan untuk membahas persimpangan dinamis antara hambatan spasial dan kecenderungan pemanfaatan "mediated citizenhip" oleh warga desa dalam mengakses layanan publik. Penting untuk memetakan bagaimana masyarakat desa berinteraksi dengan pemberi layanan otoritatif di tingkat pemerintah daerah, yang tidak dilakukan secara langsung, melainkan melalui mediasi pihak ketiga, yaitu LSM lokal yang melaksanakan program di desanya. Berdasarkan konteks Desa Oi Bura, kecenderungan pemanfaatan jasa mediator "LAKPESDAM PCNU Kabupaten Bima" dalam mengakses pelayanan publik (khususnya identitas permukiman) mulai terbentuk karena dipicu oleh pertimbangan masyarakat miskin terhadap tata ruang. hamparan wilayah desanya dengan lokasi penyedia layanan yang tentunya berdampak pada pengeluaran keuangan dan faktor keparahan birokrasi yang harus dilalui saat mengakses layanan dasar tersebut. Meskipun identitas kependudukan seharusnya diperoleh secara otomatis berdasarkan status formal sebagai warga negara Indonesia, pada praktiknya akses masyarakat miskin terhadap layanan dasar dicapai melalui peran mediasi pihak ketiga. Keterbatasan daya tanggap, akuntabilitas, dan kapasitas kelembagaan penyedia layanan untuk bertindak proaktif dalam menyelesaikan masalah publik semakin membuka peluang untuk "kelanggengan" fasilitasi interaksi negara-warga oleh pihak ketiga.

Kata kunci: akses, citizenship, mediator, layanan, ruang.

\section{Introduction}

How villagers gain access to public services that relate closely to their right of citizenship? A question that is at the core of this paper. Due to special factors, access to public services is not sought directly by villagers from service providers but is obtained by utilizing the presence of "broker or mediator" actors who are willing to mediate their rights claiming for public services to the state. The intermediary actor came from elements of NGO that is currently implementing programs in their village, where the program has nothing to do with issues of public services (basic services). Rather than utilizing the merit of the local village government officials, citizens choose the path of the utilization of access to legal identity (residential identity), through the NGO due to the consideration of the absence of fees charged to them on the "merit" of the maintenance of these identities.

If the management of residential identity is mediated by the local village government officials, each person is required to deposit a certain amount of money as a substitute for transportation costs plus the mediator's other variants of expenses and "facilitation fees" for certain individuals working in the institution of service providers to accelerate the publishing of the desired documents. It is not only the village government apparatus that operates in this intermediary realm, certain individuals in the village also take part.

In other words, this paper aims to present an overview of how citizens relate or establish relationships indirectly with power holders and state institutions through intermediaries. As we understand that this pattern of indirect power relations is not a 
new phenomenon in the political system of post-colonial countries such as Indonesia. Most of the state-society interaction in contemporary Indonesia takes the indirect form (Berenschot, 2015) because accessing the service is not a matter that working smoothly so just as in desire, especially among the poor and oppressed.

Citizens in this category rely on mediators to help them navigate the various bureaucratic affairs that seem somewhat complex and cumbersome. The access of villagers, especially the poor and marginalized categories, to public services and/or social welfare is generally mediated by the local elites. The pattern of "mediated citizenship" in the life of rural communities can be motivated by the weak institutionalization of service institutions and the imbalance of power relations that have long existed (previously created). Access to public services reflects more on personal virtue, rather than as a right that is constitutionally guaranteed to be enjoyed by every formal citizen (Sambodho, 2016).

Intermediaries may be a person skilled in establishing a connection and know the unwritten rules in bureaucracy (Sambodho, 2016). He acts as an actor who "voices for" citizens without formal or even explicit authorization attached to them (Pitkin 1967; Mansbridge 2003; in von Lieres \& Piper, 2014: 1). These intermediaries help individuals gain access to certain benefits from the state, which to them seem so difficult to supply. Through the share of intermediaries who deal with states that appear unresponsive, this kind of intermediary enables citizens to realize their rights (Berenschot, 2015).

Regardless, citizenship is generally associated with the claim to basic rights for citizens. The emphasis is not on the existence of basic rights as something inevitable, natural and normative and therefore different from human rights, but on right to have rights, which is the foundation that enables a person to have rights (Arendt, in Sommers, 2008).

The more dominant approach used in the study of citizenship can be grouped into two perspectives: citizenship as a normative issue and an analytical-empirical concept. As a normative issue, the substance of citizenship is understood through several traditions, namely the Liberal Tradition (emphasizing autonomy and freedom of choice); Social Democratic Tradition (emphasizing equality and social rights as prerequisites for achieving ideal conditions); The Republican Tradition (emphasizing the virtues of political participation, political community, and an orientation towards the common good); and Communitarian Tradition (underlining the significance of social integration and development of social capital through participation or cooperation). Meanwhile, as an analytical-empirical concept, citizenship has three main dimensions: rights, participation, and identity (Andersen \& Hoff, 2001: 2-3).

Based on the formulation of the study approach, this paper will only explore citizenship as an analytical-empirical concept, especially in the dimension of rights. And like the works of Berenschot (2015), von Lieres \& Piper (2014), and Sambodho (2016), this paper also discusses a similar topic, namely the dependence of the poor on an intermediary in dealing with the state to claim rights. The citizenship which they should be able to enjoy automatically refers to their position as formal citizens. Incapability to navigate the complexity and severity of bureaucratic affairs in the interests of the maintenance of the residential identities, which is also supported by the spatial barrier factor between the village area with the location of the service provider is the main reason why poor people in the village tend to take advantage of the existence of an intermediary that offers ease of access to particular public services. 
This paper is based on the findings of research conducted for 10 full months (August 2017-May 2018) in Oi Bura Village, Tambora District, Bima Regency, West Nusa Tenggara Province. This village was formed in 2007 as a result of the division of the main village 'Labuhan Kananga'. It consists of three hamlets, namely Sori Bura, Tambora, and Jembatan Besi. In 2016, the population of this village numbered 650 people or 160 heads of families. 10\% of them (16 families) are migrants from Bali and of course, are Hindus. Oi Bura Village is $194 \mathrm{~km}$ from Bima Regency Government Center.

The location of Oi Bura Village, which is somewhat "isolated", also complements the complexities of life that its residents feel. The high poverty rate, the improper condition of the infrastructure to support the activities and mobility of the villagers, the absence of ownership of the residential identities of most of the people, the lack of seriousness of the attention of the local government in the utilization of village potential, and the lack of adequate health and education service facilities have made Oi Bura Village very far behind compared other villages in Bima Regency (Hidayat, 2018: 92).

The factor of the spatial stretch that is too far from the Local Government is often the main obstacle for some villagers to take care of their residential identities. It takes 16 hours ( 8 hours to go, 8 hours to return) to the office of the Department of Population and Civil Registration "Dinas Kependudukan dan Catatan Sipil (DisDukCaPil)" of Bima Regency for submitting the required administrative files. Because the issuance of a residential identity cannot be done in just one day by DisDukCaPil (according to statutory provisions, the duration of managing a person's residential identity is 7 days), the residents of Oi Bura Village still have to take another 16 hours on another day to take their residential identities. Considerations of distance, length of travel time, and the amount of transportation and accommodation costs have led to the reluctance of many villagers to take care of their residential identities (ibid).

In other words, the needs of Oi Bura villagers, especially among the poor (less capable), to access certain public services provided by the government agencies often collide with these spatial constraints. As a consequence, the majority of villagers are hampered from access to being part of the coverage of state service beneficiaries. As mentioned above, spatial distance has an impact on the low quantity of individuals in Oi Bura Village who have residential identities such as birth certificates, family cards, and marriage certificates.

When a local NGO, namely LAKPESDAM PCNU Kabupaten Bima, implements the "Peduli" program in the village of Oi Bura since October 2014 until now, people have started to use the momentum of the existence of that NGO to push the need on residential identity becomes an additional part of social issues advocated by that program implementor. Peduli is a program under the coordination of the Coordinating Ministry for Human Development and Culture of the Republic of Indonesia which uses the "Social Inclusion" approach as an effort to empower marginalized communities, improve welfare, and eradicate poverty. LAKPESDAM $P B N U$ was made by that Coordinating Ministry as one of the national partners in implementing the program, so that LAKPESDAM PCNU Kabupaten Bima could also be involved in it because of this factor.

The "Peduli" program reflects the government's tactical responses to the threat of social disintegration which is feared will happen massively in Tambora District because of the emergence of a mass protest to the Government of Bima Regency in 2013-2014 that backed the plan of "Construction of Largest temple in Southeast Asia in the village 
of Oi Bura". The program is oriented towards maximizing the role of civil society actors to be able to prevent the continuity of the emergence of greater religious discrimination practices in Oi Bura Village while at the same time developing an inclusive social order so that people can synergize with one another in democratically carrying out all village development programs without discriminatory actions based on differences in religion or belief.

Based on the context of Oi Bura village, the authors will elaborate the intersection of a spatial barrier factor (including its logical consequences) with the tendency of villagers to utilize the "mediated citizenship" starring LAKPESDAM PCNU Kabupaten Bima as the NGO that implements the "Peduli" program in Oi Bura Village. To obtain an adequate explanation, this paper will be guided by the question: How is the intersection between spatial barriers and the tendency of the utilization of "mediated citizenship" by Oi Bura Villagers in accessing public services?

\section{Research Methodology}

This study used a qualitative method with a case study approach. Qualitative research aims to uncover a variety of issues and seek answers to many questions by examining a range of individual and community settings (Creswell, 2007: 4). Through a case study, the researchers want to explore further the intersection of spatial barriers with the tendency of the Oi Bura villagers to use "mediated citizenship" in accessing public services (residential identity services) from certain institutions at the Bima Regency Government level.

Based on the technique purposive sampling, key informants as the sources of data extraction will be targeted from the organizational leaders of $L A K P E S D A M P C N U$ Kabupaten Bima and some beneficiaries (participants' activities), especially individuals who utilize the mediation of this local NGO in managing their residential identities.

To obtain the data and information that is deemed necessary, several data collection methods will be used to solve and analyze problems that have been formulated before, namely (a) Desk Study: researchers collect and translate the written data relevant to research issues; and (b) Field Study: researchers interact directly with several key informants through in-depth interviews to obtain more comprehensive data.

To describe and translate the data obtained in the field, the analysis techniques can be in the form of (a) Data collection process: the researcher collects data obtained from various sources, both primary and secondary sources related to this research; (b) Data reduction: the data that has been obtained in the field are sorted and reduced to take only important data related to this research; (c) Presentation of data as well as verification stage: important data that have been taken are then reviewed, rechecked, and presented as a discussion step towards research problems; and (d) Conclusion: the researcher takes the most important data that has been presented in the discussion of this research problem.

\section{Results and Discussion}

\section{Social Exclusion: A Trigger for NGO's Initiatives to Implement Programs in Oi Bura} Village

As mentioned in the first section, from October 2014 until now, LAKPESDAM PCNU Kabupaten Bima is a local NGO that is currently implementing the "Peduli" program in Oi Bura Village. Based on the social inclusion approach, the orientation of 
this program is aimed at empowering the lives of minority groups who are vulnerable to becoming "victims" of social discrimination as a result of differences in ethnicity and religion/belief from the majority in certain areas in Indonesia, including the village in which this study is located. Within the framework of implementing the "Peduli" program, LAKPESDAM PCNU Kabupaten Bima derived the program's big agenda into the theme "Strengthening the Peace Cadre on the Slopes of Tambora to Realize Oi Bura Village as an Inclusive Village". The formation of a cohesive and non-discriminatory social order that reflects the synergy of collaboration between residents and village administrations in carrying out development programs in a democratic manner is a fundamental goal to be seeded through this program.

Based on that goal, a series of activities have been carried out by LAKPESDAM PCNU Kabupaten Bima which not only relies on the domain of "social conflict prevention", but also intersects with other domains that are considered to be able to sustain the title of "inclusive" in Oi Bura Village. These activities include (i) Youth Tourism Training; (ii) Conflict Prevention and Mediation Technique Training for Tambora Slope Peace Cadres; (iii) Cultural Festival; (iv) Social Awareness Schools: Facilitation, Village Governance, Social Analysis, Journalism, and Women's Empowerment; ( v ) Pre-Harvest Soil Ritual; and ( vi ) Local Business Development and Village Potential Festival (The 2014-2016 Program Work-Plan of LAKPESDAM PCNU Kabupaten Bima).

"... In general, the substantive outcomes of the implementation of the "Peduli" Program in Oi Bura village for this recent three years are the increasing salience of the village community conversations about social inclusion discourse. Changes of this substantive occurs not because of their own citizens' awareness on the concept, but rather triggered by the presence of external actor such as our organization who have begun to introduce conflict prevention strategies discursively to them. The awareness of villagers, in my opinion, is now starting to lead to an understanding of what is meant by citizenship and civic participation, which is obtained through the dominant discussion and deliberation activities that were held on our initiative with residents. Social inclusion has become a public discourse over there because each party has begun to realize that the discursive approach is the most effective conflict prevention strategy applied. This can be seen in various series of deliberations as well as cultural activities that involve both parties, namely followers of Islam as the majority and Hindus as a minority. To note, the program initiatives we are doing today in the village of Oi Bura backed solely by the contentious relations between two groups of citizens of different religions in 2013 and, coupled again by the high intensity of mass protests on the existence of Hindu temple at once issue Largest Development in Southeast Asia in this village ..." [Interview with Asrul Raman, Chairman of LAKPESDAM PCNU Kabupaten Bima, on October 9 2017].

Efforts to encourage the realization of a citizen-based social structure in Oi Bura Village that characterizes inclusive life among residents without ethnic/religious differences to eliminate the potential (symptoms) of more massive religious discrimination practices, as carried out by LAKPESDAM PCNU Kabupaten Bima, can be authentic evidence if the civil society organizations can also have the ability like state agencies to carry out community empowerment agenda and/or social development program.

"... All the program beneficiaries in the Oi Bura Village, both residents and village government officials, we drive to have an awareness of the significance of social inclusion. To sustain it, knowledge about other things also be transferred to them by contributing some 
experienced practitioners who own good fortune as a speaker or facilitator, namely in the form of conflict management techniques, methods of data collection of the village potentials as a base village development planning, engineering social analysis, the pattern of village's financial administration, etc. The involvement of the various elements of society in any program activities, We orientate it as an inclusive role model for village government and residents that the seeds of social cohesion can be sown in the village when an activity can be accessed easily by anyone who wants to be a participant in it ..." [Interview with Abdul Haris, Program Officer, on October 12, 2017].

The description of the role of LAKPESDAM PCNU Kabupaten Bima to sow the seeds of social inclusion in Oi Bura Village, as shown above, without being balanced with an adequate explanation of the contribution of other actors in the same work domain and context, is inevitable because LAKPESDAM PCNU Kabupaten Bima is the only civil society organization that concerned with the problem of social exclusion or the discriminatory practices of religious minorities that occurred in the village. This local NGO was the first to position Oi Bura Village as a location for implementing social empowerment programs to eliminate the negative impact of social exclusion that appears in the lives of village residents. The practice of limiting the access of certain groups to resources, services, information, and others by other groups in Oi Bura Village is to be reduced in level or massiveness through the implementation of the Peduli Program which has been going on for the last four years to create an inclusive social life there.

The singular existence of LAKPESDAM PCNU Kabupaten Bima as an actor initiating an inclusive life in Oi Bura Village is not happening without cause. The absence of funding support from international donor agencies or alternative funding sources (such as the central government and local governments) is the main reason for the passivity of other civil society organizations to look at the social exclusion problem plaguing certain groups of citizens in Oi Bura Village. Moreover, the problem of discrimination of religious minorities that took place in the village may be considered "not as the sexy issue" that must be fought by them. This suggests that all civil society organizations, especially NGOs, in Bima Regency are still very dependent on funding from funding agencies to implement a program. The image as "donor-driven NGOs" has remained closely attached to their organizational operations over the years.

The government of Bima Regency also seems not wholeheartedly trying to solve this problem. This conclusion is made referring to what the local government has done in handling cases related to the context of Oi Bura Village. To quell mass protests on the development issues of the largest temple in Southeast Asia, solutions in applied rather dwell on the provision of a technocratic explanation about it. There are absolutely no follow-up steps in the form of special programs that are initiated to create an inclusive life in Oi Bura Village. LAKPESDAM PCNU Kabupaten Bima appeared to be the sole observer of the social exclusion problem that has been taking place over there, although its contribution does not escape from the encouragement of the availability of funding support from funding agencies to carry out such empowerment works. 


\section{Articulation of the Residential Identity Needs as Complementary to NGO's Advocacy Issues}

Referring to the previous description, the presence of LAKPESDAM PCNU Kabupaten Bima in Oi Bura Village is in the framework of implementing the "Peduli" program under the coordination of the Coordinating Ministry for Human Development and Culture of the Republic of Indonesia, which puts forward the application of a social inclusion approach to empowering marginalized communities, improve welfare, as well as combating poverty. On a narrower scale, this program's agenda is focused on empowering the lives of minority groups who are vulnerable to becoming "victims" of social discrimination as a result of differences in ethnicity and religion/belief in certain regions in Indonesia. Involving with this agenda, LAKPESDAM PCNU Kabupaten Bima then derived its program orientation to "Strengthening the Peace Cadre on the Slopes of Tambora to Make Oi Bura Village an Inclusive Village".

The domain of "overcoming and preventing social exclusion based on differences in religion/belief" has become the basis for this local NGO in formulating the forms of activities carried out in the program location village. Even so, other domains have also been targeted to sustain the efforts to manifest Oi Bura Village as an "inclusive village". Training on Conflict Prevention and Mediation Techniques for Peace Cadres of Tambora Slope; Social Awareness Schools: Facilitation, Village Governance, Social Analysis, Journalism, and Women's Empowerment; Tourism Youth Training; Cultural Festival; Pre Harvest Soil Ritual; and Local Business Development and Village Potential Festival are the series of activities that reflect a combination of the main domain and additional domains to achieve the program's basic outcomes.

In the course of implementing the program from year to year, from October 2014 to the present, the forms of activities carried out by LAKPESDAM PCNU Kabupaten Bima are no longer concentrated only on the various activities as mentioned above. This NGO's attention has also started to lead to the issue of "the limited number of villagers who have residential identities", referring to one of the results of the social analysis or mapping crucial problems of Oi Bura villagers, which was done in the early period of the program (October 2015-October 2016). To solve this identity problem, the program officers presented many citizens in the event of social analysis activities that took place more than once. Participants asked the LAKPESDAM PCNU Kabupaten Bima to be willing to make these issues to be part of its work or advocacy.

LAKPESDAM PCNU Kabupaten Bima then agreed to make managing the residential identity of Oi Bura Villagers an additional work agenda. This local NGO personnel have also gone on to assert that any individual who requires the residential identities could reach them at the next meeting for the sake of collecting and submitting the file of administrative requirements. Files that are deemed complete and meet these requirements are then submitted to the service provider at the DisDukCaPil Office to be processed accordingly.

Some issue birth certificates, family cards, and/or marriage certificates have to be brought along by the personnel of the LAKPESDAM PCNU Kabupaten Bima to the village of Oi Bura lapse of 2 weeks after the previous meeting to be submitted to the citizens (according to the work-plan, the program implementer's field visits to Oi Bura Village are routinely carried out once every 2 weeks. 1 visit with a duration of 3 days with a live-in pattern). This routine of managing the state benefits is repeated with the same pattern or rhythm until now. 
“... Until May 2018, the personnel of the LAKPESDAM PCNU Kabupaten Bima already facilitated the settlement of hundreds of request of the residential identities to more closely align the poor village of Oi Bura for free (without a penny was charged to each citizen as the cost of services instrumentality), with details: 70 Marriage Certificates, 160 Birth Certificates, and 240 Family Cards ..." (Interview with Abdul Haris, Program Officer of LAKPESDAM PCNU Kabupaten Bima, on May 31, 2018).

In this realm, if we refer to the argument of von Lieres \& Piper (2014), then LAKPESDAM PCNU Kabupaten Bima has positioned himself as an NGO that played a mediation role of "spoken to" citizens who want it be represented (NGOs perform s an intermediary role by speaking for the citizens they wish to represent).

\section{The intersection of Spatial Barriers and Bureaucratic Severity with Mediated Citizenship}

Relevant to the context of the village of Oi Bura, aligned with the stretch of barrier spatial condition of hopelessness or even passivity of the authoritative institution or the formal public service provider, and the subtleties of the bureaucratic process in accessing the service, the acquirement of citizenship as a right has to be intensively fought by a group of citizens (especially the poor), although this was done not directly, but through third parties. LAKPESDAM PCNU Kabupaten Bima has acted as a mediator that facilitated the interaction between villagers and local governments for the availability of access to basic services, namely residential identities provided by public institutions.

This context further complements the definitions of citizenship, as formulated by Tilly (2000); Lund (2011); and Holston (2008), as a way of allocating resources, and consequently being the subject of endless negotiations and possibly manifesting in a multitude of practices or ideas. More than that, citizenship, especially in the framework of service delivery, should not only be observed through a standard normative lens but also need to be explored through the actual negotiations that occur so that the types of citizenship ideas that emerge in the daily practice of accessing services can be mapped.

Understanding how the daily practice of citizenship translates into actual service access is important because it reflects how the whole idea of citizenship is placed into the broader notion of "democratization" that promises good governance and good quality service (Speer, 2012). By placing the issue of "service delivery" into a broader notion of citizenship, we can move towards the stage of service delivery as social justice, not as a mere market transaction (Williams, in Sambodho, 2016).

The factor of the formal service providers unresponsiveness to immediately resolve public issues, which in essence becomes their constitutional obligation, equipped by a far stretch of the spatial between village location with the site of the institution plus the steep road (complexity procedures) of bureaucratic affairs which would be faced when accessing certain service were the row of complicated conditions that paved the way, made it possible, and at the same time reinforced the need for citizens to have a third party presence to facilitate their interaction with the state. The mediating role played by LAKPESDAM PCNU Kabupaten Bima in mediating the needs of the residential identities of the poor in Oi Bura Village is a "panacea" for the flawed formal representation of public institutions at the local level.

The case of the Oi Bura Villagers reflects that mediation can be viewed as a practice that sometimes reflects, and perhaps does reinforce, the lack of democratic 
relations between the state and its citizens. It appears in a situation of limited efficacy democratic representation through formal institutions or formal actors (von Lieres \& Piper, 2014: 2). Provision of access to state benefits occurs through facilitating interactions with front-line bureaucrats (Berenschot \& van Klinken, 2018: 103).

The case also reflects that democratic representation politics can be facilitated by a third party mediation, either to bring marginalized groups into the decision-making process of state or to establish other forms of agency politics or nationality among marginalized groups which can be recognized by the state and then it will respond. Mediation can, at times, be a form of democratic politics, capable of overcoming some of the weaknesses of liberal representative democracy and participatory governance. It refers to informal forms of representation by intermediaries who speak for groups of citizens, and vice versa (von Lieres \& Piper, 2014: 5).

The mediation that mediators did nullifies the access experience to basic services as a right. Instead, people consider this access depends indeed on the personal obligation between the citizens and their intermediaries and between intermediaries and front-line service providers (Berenschot, Hanani \& Sambodho, 2018). The informal nature of citizen-state interactions helps interpret the observation that rights-based discourse is relatively absent in Indonesia (Gibbings, in Berenschot \& van Klinken, 2018: 106).

The dependence on informal connections, on the framework of interaction between the residents of the Oi Bura Village-LAKPESDAM PCNU Kabupaten BimaDisDukCaPil Office, emphasizes a response to the limited capacity of state institutions to perform ideally according to the demands of the principle of "excellent service".

\section{Conclusion}

Constitutionally, the state is obliged to guarantee the fulfilment of all citizenship rights for every individual who is the subject of its social contract. Even so, to a certain extent, the state is powerless to do this, so that it is labelled unresponsive and has low institutional capacity. Many factors can hinder or limit the realization of a person's citizenship rights by the state. The emergence of the terms cultural injustice, social and economic injustice, and injustice of political representation, as formulated by Hiariej \& Stokke (2017), marks the powerlessness of the state in the domain of citizenship.

The spatial barrier as characteristic of "isolation" of Oi Bura Village from the Local Government area (including its financial consequences), plus a factor of bureaucratic severity and limited levels of responsiveness of public service providers become impetuses for the poor people's initiatives to take advantage of the presence of a third party as facilitation media for their interaction with state institutions to access basic services in the form of residential identities.

Although these residential identities should be obtained automatically based on their formal status as Indonesian citizens, in practice the access of the poor people in Oi Bura Village to certain basic services is obtained through the mediation role of NGO that is implementing programs in their village. The intersection of spatial constraints plus other factors has intersected with the tendency of the utilization of "mediated citizenship" by Oi Bura villagers to access the basic services provided at the local level state institutions. The intimate personal relations with LAKPESDAM PCNU Kabupaten Bima has been used by the villagers as a base insistence that the NGO should include their residential identity needs as a special advocacy issue that must be articulated to the local government while mediating the possibility of easy and cheap access gains. 
Reflecting on the case, the authors recommend that providers of basic services at the local level should always be intensive to forge their responsiveness and accountability levels in implementing the formal obligation, be proactive to solve public issues which already been identified by the government institutions at the lower level (village government), and begin to cultivate public service governance based on impersonal values to negate the image of the complexity of bureaucratic affairs in the eyes of citizens.

\section{About Authors}

Rahmad Hidayat is a lecturer at the Department of Administrative Science of STISIP Mbojo Bima. He obtained his M.A. in Human Rights and Democracy Studies from the Department of Politics and Government, Faculty of Social and Political Sciences, Universitas Gadjah Mada. In 2015, he attended the Spring Course on "Democratization in the Global South" at the Faculty of Social and Political Sciences, University of Oslo Norway, which was tutored directly by Prof. Olle Tornquist and Prof. Kristian Stokke. His area of interests relates mainly to certain political issues such as citizenship, the welfare state, human rights, democracy, and social movement.

Akhyar is a lecturer at the Department of Administrative Science of STISIP Mbojo Bima. In 2017, He completed his Master Degree in Public Administrative Science at the Universitas Merdeka, Malang.

Muhammad Sauki is a lecturer at the Department of Communication of STISIP Mbojo Bima. In 2015, He obtained his M.A. in Communication Studies from the Department of Communication, Faculty of Social and Political Sciences, Universitas Gadjah Mada.

\section{Acknowledgements}

We gratefully thank to the Institute for Research and Community Service (Lembaga Penelitian dan Pengabdian Masyarakat) of STISIP Mbojo Bima and LAKPESDAM PCNU Kabupaten Bima. Both institutions gave huge supports for this research.

\section{References}

Andersen, G. J. \& Hoff. J. (2001). Democracy and Citizenship in Scandinavia. New York: Palgrave.

Berenschot, W. (2015). Mediated Citizenship and Indonesia's Postcolonial State. Working Paper. Presented at the International Conference 'From Clients to Citizens? Citizenship in Democratising Indonesia' in Yogyakarta on 8-10 December 2016 which Organised by Royal Netherlands Institute for Southeast Asian and Caribbean Studies (KITLV) and Universitas Gadjah Mada.

Berenschot, W., Hanani, R. \& Sambodho, P. (2018). Brokers and Citizenship: Access to Health Care in Indonesia. Citizenship Studies, 22(2). doi:10.1080/13621025.2018.1445493. 
Berenschot, W. \& van Klinken, G. (2018). Informality and Citizenship: The Everyday State in Indonesia. Citizenship Studies, 22(2), 95-111, DOI: 10.1080/13621025.2018.1445494.

Creswell, J. W. (2007). Qualitative Inquiry and Research Design: Choosing Among Five Approaches. Second Edition. Thousand Oaks: Sage Publications.

Hiariej, E. et. al. (2016). Sejarah Politik Kewargaan di Indonesia: Politik Pengakuan, Politik Redistribusi Kesejahteraan dan Politik Representasi. Yogyakarta: Polgov DPP UGM.

Hidayat, R. (2018). Segregasi Residensial dan Intersubyektivitas Kewarganegaraan Masyarakat Desa Oi Bura Kecamatan Tambora Kabupaten Bima. Journal of Governance, 3(1), 80-100.

Holston, J. (2008). Insurgent Citizenship: Disjunctions of Democracy and Modernity in Brazil. Princeton, NJ: Princeton University Press.

von Lieres, B. \& Piper, L. (eds.). (2014). Mediated Citizenship: The Informal Politics of Speaking for Citizens in the Global South. New York: Palgrave Macmillan.

Lund, C. (2011). Property and Citizenship: Conceptually Connecting Land Rights and Belonging in Africa. Africa Spectrum, 46(3), 71-75.

Sambodho, P. (2016). Menyindir the State: Everyday Citizenship Claims in a West Java Village. Working Paper. Presented at the International Conference 'From Clients to Citizens? Citizenship in Democratising Indonesia' in Yogyakarta on 8-10 December 2016 which Organised by Royal Netherlands Institute for Southeast Asian and Caribbean Studies (KITLV) and Universitas Gadjah Mada.

Sommers, M. R. (2008). Genealogies of Citizenship: Markets, Statelessness, and the Right to Have Rights. Cambridge: Cambridge University Press.

Speer, J. (2012). Participatory Governance Reform: A Good Strategy for Increasing Government Responsive-ness and Improving Public Service? World Development, 40(12), 2379-2398.

Stokke, K. \& Hiariej, E. (eds.). (2017). Politics of Citizenship in Indonesia. Jakarta: Yayasan Pustaka Obor Indonesia, in collaboration with Polgov Fisipol UGM and the University of Oslo.

Tilly, C. (2000). Processes and Mechanisms of Democratization. Sociological Theory, 18(1), $1-16$. 